\title{
Revista do

\section{PARA UMA CULTURA DO CONSENSO: A NECESSÁRIA REFORMA NOS CURSOS DE DIREITO}

Sabrina Jiukoski da Silva ${ }^{1}$

\section{RESUMO}

Este artigo analisa a cultura da sentença, fortemente presente na sociedade brasileira, e, a partir das recentes alterações legislativas e da realidade do ensino do Direito no Brasil, desenvolve propostas para mudanças nas grades curriculares dos cursos jurídicos. Conclui-se, assim, pela adoção de uma metodologia de ensino participativo preocupada em formar profissionais críticos e reflexivos do Direito, juntamente com a inserção de disciplinas que propiciem a mudança de mentalidade dos operadores do Direto para construção de uma cultura do consenso - disciplinas que tratem adequadamente da mediação e da conciliação.

Palavras-Chaves: Cultura da sentença. Cultura do consenso. Ensino do Direito.

\section{THE CULTURE OF CONSENSUS: A REFORM NECESSARY IN THE COURSES OF LAW}

\begin{abstract}
This article analyzes the culture of sentence present in Brazilian society. From the recent legislative amendments and the reality of Law teaching in Brazil, develops proposals for the necessary changes in the curriculum of legal courses. It is suggested the adoption of a participatory teaching methodology concerned with training critical and reflective Law professionals, along with the insertion of disciplines that allow the change of the mentality of the Law operators to build a consensus culture.
\end{abstract}

Keywords: Culture of sentence. Culture of consensus. Law teaching.

\footnotetext{
${ }^{1}$ Doutoranda e mestra em Direito pelo Programa de Pós-Graduação em Direito da Universidade Federal de Santa Catarina (PPGD/UFSC). Pós-graduada em Direito Processual Civil pela Faculdade CESUSC. Graduada em Direito pela Faculdade CESUSC. Bolsista CNPq. Membro do Grupo de Pesquisa de Direito Civil Contemporâneo. E-mail: sjiukoski@gmail.com.
} 


\section{INTRODUÇÃO}

O número de demandas judiciais no Brasil cresce exponencialmente. O último relatório divulgado pelo Conselho Nacional de Justiça (2018) revelara que no ano de 2017 foram registrados 80,1 milhões de processos em trâmite no Poder Judiciário brasileiro, enquanto em 2009 eram 59,1 milhões. Trata-se de um crescimento acumulado de 31,9\% no período (2009-2017). Em contrapartida, a morosidade na prestação jurisdicional é um dos problemas mais relatados pelos jurisdicionados, além da formalidade e da burocratização.

A sociedade brasileira tem como método, dito tradicional, de administração dos conflitos o judicial. Trata-se do que a doutrina vem denominando, na última década, de cultura da sentença, na qual prepondera a necessidade de resolução dos conflitos por meio de uma decisão judicial proferida por um terceiro imparcial, o magistrado (o Estado-juiz). No entanto, essa procura incessante pela tutela do Poder Judiciário vem acarretando o acréscimo significativo das demandas judiciais e, como corolário, a "crise da justiça" brasileira, interferindo, em vias reflexas, no direito ao acesso à justiça.

Segundo estudos de Boaventura de Sousa Santos (2007), a problemática é fruto, entre outros fatores, da perspectiva cultural e da mentalidade dos profissionais na área do Direito. As faculdades de Direito, enquanto locais de circulação dos postulados da dogmática jurídica, criam uma cultura de exterioridade e têm servido para a formação de profissionais sem um maior comprometimento com a sociedade. Os docentes acabam utilizando-se do método tradicional de ensino - pedagogia da transmissão ou educação bancária - para a formação dos alunos, e poucos são aqueles que se voltam ao tratamento eficaz dos conflitos. Fruto dessa formação, os novos docentes acabam utilizando a metodologia daqueles que os precederam; e os advogados, magistrados, defensores públicos, membros do Ministério Público e outros profissionais da área acabam habituados à cultura da sentença.

Dessa forma, este artigo tem como escopo, a partir do raciocínio dedutivo, verificar se é possível uma mudança de mentalidade dos juristas brasileiros capaz de transcender o paradigma da cultura da sentença. Se sim, como? Nesse contexto, o principal desafio que se coloca é a alteração das grades curriculares dos cursos jurídicos e a adoção de uma metodologia de ensino preocupada em atender as necessidades atuais dos profissionais e da sociedade brasileira. As faculdades de Direito, atualmente, não se mostram interessadas na fomentação de métodos alternativos ao ensino tradicional, tampouco na educação jurídica voltada para a eficaz solução dos conflitos ou, ainda, na inserção de uma disciplina que 
abarque os métodos consensuais de resolução de conflitos, tais como: negociação, conciliação, mediação e arbitragem.

Desenvolvendo os objetivos específicos deste artigo, na primeira seção discorre-se sobre o paradigma da cultura da sentença no Brasil e as recentes alterações legislativas; no segundo tópico é apresentado o ensino tradicional do Direito nas faculdades brasileiras; e, no terceiro ponto, aborda-se a necessidade de renovação do ensino tradicional dos cursos jurídicos como alternativa ao paradigma da cultura da sentença, propondo-se mudanças significativas nos métodos de ensino e nas grades curriculares dos cursos. Por último, serão tecidas as considerações finais e conclusivas.

\section{A CULTURA DA SENTENÇA E AS POLÍTICAS DE TRATAMENTO ADEQUADO DOS CONFLITOS}

No Brasil, a jurisdição é praticamente o único meio utilizado pelos indivíduos para solução de seus conflitos. Culturalmente, na sociedade brasileira está inserida a ideia de que todo e qualquer conflito necessita ser apresentado ao Poder Judiciário e resolvido sob a forma de uma solução adjudicada, dotada de força estatal imperativa e coercitiva, fundada na lógica de que uma das partes sairá "vencedora" e a outra, "perdedora" (SALLES, 2006).

Ao analisar o histórico nacional, Boaventura de Sousa Santos (2007) afirma que essa credibilidade do uso da via judicial tem suas raízes no processo de redemocratização do país e na promulgação da Carta Constitucional em 1988. Ao instituir um Estado Democrático de Direito - com ênfase na soberania, na cidadania, na dignidade da pessoa humana, nos valores sociais do trabalho e da livre iniciativa e no pluralismo político (art. $1^{\circ}$ ) -, destinado a assegurar o exercício dos direitos sociais e individuais, a Magna Carta inovou ao ampliar os direitos e as garantias constitucionais (art. $5^{\circ}$ ), ao incluir não apenas os direitos civis e políticos (art. 14), mas também os direitos sociais (art. $6^{\circ}$ ). E, ainda, passou a assegurar a todos os cidadãos o acesso à justiça (art. $5^{\circ}$, inc. XXXV), o devido processo legal (art. $5^{\circ}$, inc. LIV), o contraditório e a ampla defesa (art. $5^{\circ}$, inciso LV), a assistência jurídica gratuita aos que comprovarem insuficiência de recursos financeiros (art. $5^{\circ}$, inciso LXXIV) e a prestação jurisdicional em tempo razoável (art. $5^{\circ}$, inc. LXXVIII).

O Poder Judiciário passou a ser o protagonista do cenário público; e os cidadãos, tendo consciência dos seus direitos, passaram a recorrer aos tribunais com frequência para protegerem ou exigirem a efetiva execução desses direitos constitucionais (SANTOS, 2007). 
Em outras palavras, o Estado passou a garantir a realização dos direitos fundamentais com acesso ao Poder Judiciário, que, segundo Mauro Cappelletti e Bryant Garth (1988, p. 12), é “o requisito fundamental - o mais básico dos direitos humanos - de um sistema jurídico moderno e igualitário que pretende garantir e não apenas proclamar os direitos de todos". Assim, os cidadãos brasileiros acabaram dependentes desse sistema para fazer valer seus direitos, de tal forma que a execução deficiente de políticas públicas ou pequenos conflitos entre particulares passaram a ser motivo de procurar frequentemente o Poder Judiciário.

Todavia, em face da excessiva busca de tratamento dos conflitos por meio do Poder Judiciário, a sociedade acabou sobrecarregando o sistema com conflitos que poderiam facilmente ser resolvidos através do diálogo entre as partes.

Nesse sentido, Lançanova (2014, p. 156) dispõe:

Em relação ao grande volume de processos que sobrecarregam o Judiciário, isso se deve a uma cultura cidadã do conflito, que foi criada pela sociedade ante a Constituição Federal de 1988, que prevê a garantia de acesso à justiça, o que acabou nos tempos de hoje tornando o Poder Judiciário uma espécie de "balcão de reclamações". Nesse sentido, as pessoas se dirigem ao Judiciário para demandar qualquer espécie de problema e para exercer o seu direito de cidadão. Em muitos casos, os cidadãos, também, por falta de divulgação, não têm conhecimento que o conflito pode ser resolvido de outras maneiras alternativas, não sendo necessário acionar o Poder Judiciário. Essa busca incansável por levar qualquer espécie de conflito à apreciação do Poder Judiciário tem sido uma das causas da avalanche de processos que abarrotam o Judiciário, e o mesmo já não consegue dar vazão ao enorme número de ações judiciais.

O modelo adotado pelo Estado está cada vez mais afastado dos interesses da sociedade e sobrecarregando o Poder Judiciário. A estrutura desenhada tornou a prestação jurisdicional obsoleta, sendo incapaz de atender às centenas de demandas que são instauradas diariamente e não cumprindo com a acepção de acesso à justiça esperada por todos.

Desta forma, visando garantir o direito fundamental ao acesso à justiça, o Conselho Nacional de Justiça instituiu, por meio da Resolução nº 125, de 29 de novembro de 2010, a Política Judiciária Nacional de tratamento adequado dos conflitos de interesse no âmbito do Poder Judiciário. Determinou aos órgãos judiciários a incumbência, além da solução adjudicada mediante sentença, de oferecer outros mecanismos de solução de controvérsias, com destaque aos chamados meios consensuais, mediação e conciliação ${ }^{2}$, bem

\footnotetext{
${ }^{2}$ Utilizando a conceituação do CNJ (2017), “a Mediação é uma forma de solução de conflitos na qual uma terceira pessoa, neutra e imparcial, facilita o diálogo entre as partes, para que elas construam, com autonomia e solidariedade, a melhor solução para o problema. Em regra, é utilizada em conflitos multidimensionais, ou complexos. A Mediação é um procedimento estruturado, não tem um prazo definido, e pode terminar ou não em

Rev. do Cejur: Prestação Jurisdicional, Florianópolis v.7 n.1, p.125-143, Janeiro-Dezembro. 2019.
} 
como prestar atendimento e orientação ao cidadão (art. $1^{\circ}$ ). Ademais, estabeleceu aos tribunais a criação de núcleos e métodos consensuais e autocompositivos de forma permanente $\left(\operatorname{art} .7^{\circ}\right)$.

O objetivo central da Resolução é fomentar a substituição da solução adjudicada dos conflitos por mecanismos consensuais de resolução de conflitos, como a conciliação e a mediação, como se infere nas colocações de Kazuo Watanabe (2017):

\begin{abstract}
A instituição de semelhante política pública pelo CNJ, além de criar um importante filtro da litigiosidade, estimulará em nível nacional o nascimento de uma nova cultura, não somente entre os profissionais do direito, como também entre os próprios jurisdicionados, de solução negociada e amigável dos conflitos. Essa cultura terá inúmeros reflexos imediatos em termos de maior coesão social, e determinará, com toda a certeza, mudanças importantes na organização da sociedade, influindo decisivamente na mudança do conteúdo e orientação do ensino universitário na área do Direito.
\end{abstract}

Ademais, o artigo $6^{\circ}$, inciso $\mathrm{V}$, da Resolução $\mathrm{n}^{\circ} 125 / \mathrm{CNJ}$ reconhece que para desenvolvimento dessa rede, caberá ao CNJ buscar a cooperação dos órgãos públicos competentes e das instituições públicas e privadas da área de ensino, para a criação de disciplinas que propiciem o surgimento da cultura da solução pacífica dos conflitos, de modo a assegurar que, nas escolas da magistratura, haja módulo voltado aos métodos consensuais de solução de conflitos, no curso de iniciação funcional e no curso de aperfeiçoamento.

Complementando, o Código de Processo Civil de 2015 reforçou a necessidade de transcender a cultura da sentença com auxílio dos meios consensuais de resolução de conflitos, especialmente dentro do Poder Judiciário. Entre outros, o artigo $3^{\circ}$ do CPC/2015, em seu parágrafo segundo, dispõe ser obrigação do Estado promover, sempre que possível, a solução consensual dos conflitos, bem como dos juízes, advogados, defensores públicos e membros do Ministério Público estimular as sessões de conciliação e mediação, ou de outros métodos de solução consensual, inclusive no curso do processo judicial (art. $3, \S 3^{\circ}$ ).

O CPC/2015 trouxe transformações que visam aproximar as partes, sem uma direta confrontação de seus interesses. Entre as alterações, as técnicas de mediação e conciliação no sistema processual civil destacam-se como fórmula capaz de solucionar

acordo, pois as partes têm autonomia para buscar soluções que compatibilizem seus interesses e necessidades". Já a "conciliação é um método utilizado em conflitos mais simples, ou restritos, no qual o terceiro facilitador pode adotar uma posição mais ativa, porém neutra com relação ao conflito, e imparcial. É um processo consensual breve, que busca uma efetiva harmonização social e a restauração, dentro dos limites possíveis, da relação social das partes". 
adequadamente certos tipos de conflitos (GONÇALVES; SEGALA, 2016). Ainda, recentemente, o $\mathrm{CNJ}$ traçou outro passo importante para o tratamento dos conflitos e, ao mesmo tempo, para desafogar o Poder Judiciário. Trata-se do Provimento nº 67, de 26 de março de 2018, que autorizou a oferta dos procedimentos de conciliação e mediação nos serviços notariais e de registro no Brasil.

Entretanto, os desafios não findam com a construção dessas políticas públicas de tratamento de conflitos ou pela aprovação de um sistema normativo. A cultura da sentença está presente na mentalidade dos operadores do Direito que, consoante discorre Boaventura de Santos Souza (2007), a partir de sua formação acadêmica conservadora alimentam uma cultura processual, dogmática e adversarial. A cultura da sentença está fomentada no habitus ${ }^{3}$ dos juristas, na maneira de operar o Direito e conduzir os conflitos instaurados.

Contudo, a preocupação fundamental deve ser, cada vez mais, com a justiça social, "com a busca de procedimentos que sejam conducentes à proteção dos direitos das pessoas comuns" (CAPPELLETTI; GARTH, 1988, p. 93) ${ }^{4}$. Para tanto, a mudança de mentalidade e novas atitudes dos operadores do Direito ainda são necessárias, ampliando a promoção do direito ao acesso à justiça ${ }^{5}$ através do uso das políticas públicas de tratamento dos conflitos que, pouco a pouco, estão crescendo e se fortalecendo.

Assim, na próxima seção verifica-se a realidade do ensino jurídico no Brasil, destacando-se a metodologia e a grade curricular de formação. Posteriormente são apresentadas as mudanças necessárias no ensino para transcender a cultura da sentença.

\footnotetext{
${ }^{3}$ Pierre Bourdieu (1972) define habitus como o sistema de disposições duráveis que não resultam da obediência a uma regra. O habitus, assim, seria produto de estratégias que não têm uma finalidade explícita fundada em um conhecimento racional das condições objetivas. Essas estratégias não são produzidas por um determinismo mecânico, mas são objetivamente ajustadas às diversas situações (SCKELL, 2016, p. 159-170).

${ }^{4}$ Os autores defendem que "[...] os valores centrais do processo judiciário mais tradicional devem ser mantidos. O 'acesso à justiça' precisa englobar ambas as formas de processo" (CAPPELLETTI; GARTH, 1988, p. 93).

5 “O acesso à justiça é direito fundamental, previsto no art. $5^{\circ}, \mathrm{XXXV}$, da Constituição da República Federativa do Brasil - 1988, consistente na perspectiva de que a 'lei não excluirá da apreciação do Poder Judiciário lesão ou ameaça a direito'. Registre-se que a redação constitucional apresenta distorção terminológica, levando a crer que Acesso à Justiça identifica-se com a tutela do Poder Judiciário, quando, adequadamente, o ingresso ao Poder Judiciário é apenas uma das fontes do seu conceito" (GONÇALVES; SEGALA, 2016, p. 227).
}

Rev. do Cejur: Prestação Jurisdicional, Florianópolis v.7 n.1, p.125-143, Janeiro-Dezembro. 2019. 


\section{A REALIDADE DO ENSINO JURÍDICOS NO BRASIL}

Desde a inauguração dos primeiros cursos jurídicos no século XIX, o ensino do Direito prevalece quase que inalterado no Brasil ${ }^{6}$. Os princípios e as orientações pedagógicas permanecem no tempo, mesmo com a proliferação das universidades e faculdades por todo o país $^{7}$ e com as tentativas de aprimoramento do ensino diante de uma série de reformas nos diversos períodos históricos. O ensino do Direito no país parte do pressuposto de que o conhecimento do sistema jurídico é suficiente para a obtenção de êxito no processo de ensinoaprendizagem, sendo ignorada, muitas vezes, a leitura cruzada entre o ordenamento jurídico e as práticas e problemas sociais, encerrando-se o conhecimento jurídico e, consequentemente, o aluno no mundo das leis e dos códigos (SANTOS, 2007).

As instituições de ensino não demonstram preocupação em preparar profissionais críticos e reflexivos (formadores de opinião) do Direito e das necessidades da sociedade. Historicamente, inclusive, os cursos de Direito se tornaram cada vez mais teóricos, na medida em que as escolas tradicionais apresentaram resistência às necessárias atualizações e se distanciaram da realidade social (GHIRARDI, 2012, p. 24).

No entanto, as Instituições de Ensino Superior (IES), sejam públicas ou privadas, devem seguir os dispositivos constitucionais referentes ao direito à educação ${ }^{8}$, bem como o marco legislativo instituído pelo Conselho Federal de Educação, a Resolução n. 9, de 29 de setembro de 2004, que elenca as diretrizes curriculares nacionais do curso de graduação em Direito, com destaque ao artigo $3^{\circ}$ :

Art. $3^{\circ}$. O curso de graduação em Direito deverá assegurar, no perfil do graduando, sólida formação geral, humanística e axiológica, capacidade de análise, domínio de conceitos e da terminologia jurídica, adequada argumentação, interpretação e valorização dos fenômenos jurídicos e sociais, aliada a uma postura reflexiva e de visão crítica que fomente a capacidade e

\footnotetext{
6 “A história da criação de universidade no Brasil revela, inicialmente, considerável resistência, seja de Portugal, como reflexo de sua política de colonização, seja da parte de brasileiros, que não viam justificativa para a criação de uma instituição desse gênero na Colônia, considerando mais adequado que as elites da época procurassem a Europa para realizar seus estudos superiores" (FÁVERO, 2006, p. 20). Os primeiros cursos jurídicos no Brasil foram inaugurados a partir da Carta de Lei de 11 de agosto de 1827, sancionada por Dom Pedro I, com a criação das faculdades de Olinda e de São Paulo, frutos do processo de independência. O objetivo era de substituir a geração de profissionais formados na sua maioria na Universidade de Coimbra - Portugal, constituindo uma cultura jurídica tipicamente brasileira e, principalmente, formando agentes que ocupariam postos no novo aparato burocrático (VENÂNCIO FILHO, 1982; FONSECA, 2005; OLIVEIRA, 2010).

${ }^{7}$ A quantidade e expansão das faculdades “[...] não quer dizer qualidade, já que muitas instituições centraram as suas atividades apenas no ensino e, mesmo assim, um ensino marcado por uma prática pedagógica tradicional e tecnicista" (SANTOS, 2007, p. 58). O número de cursos de Direito no Brasil teve um crescimento sem paralelo nas últimas décadas, partindo de 165 escolas em 1991, 1.080 em 2008, chegando a 1.400 em 2018 (MEC, 2018). ${ }^{8}$ Ver artigo $3^{\circ}$ e capítulo III, seção I, Da Educação, da CRFB/1988.
}

Rev. do Cejur: Prestação Jurisdicional, Florianópolis v.7 n.1, p.125-143, Janeiro-Dezembro. 2019. 
a aptidão para a aprendizagem autônoma e dinâmica, indispensável ao exercício da Ciência do Direito, da prestação da justiça e do desenvolvimento da cidadania. (BRASIL, CFE, 2004).

Ainda, segundo o artigo $5^{\circ}$ do referido marco, as instituições de ensino deverão contemplar em seus projetos pedagógicos o conteúdo curricular de modo a atender três eixos:

I - Eixo de Formação Fundamental, tem por objetivo integrar o estudante no campo, estabelecendo as relações do Direito com outras áreas do saber, abrangendo dentre outros, estudos que envolvam conteúdos essenciais sobre Antropologia, Ciência Política, Economia, Ética, Filosofia, História, Psicologia e Sociologia.

II - Eixo de Formação Profissional, abrangendo, além do enfoque dogmático, o conhecimento e a aplicação, observadas as peculiaridades dos diversos ramos do Direito, de qualquer natureza, estudados sistematicamente e contextualizados segundo a evolução da Ciência do Direito e sua aplicação às mudanças sociais, econômicas, políticas e culturais do Brasil e suas relações internacionais, incluindo-se necessariamente, dentre outros condizentes com o projeto pedagógico, conteúdos essenciais sobre Direito Constitucional, Direito Administrativo, Direito Tributário, Direito Penal, Direito Civil, Direito Empresarial, Direito do Trabalho, Direito Internacional e Direito Processual; e

III - Eixo de Formação Prática, objetiva a integração entre a prática e os conteúdos teóricos desenvolvidos nos demais Eixos, especialmente nas atividades relacionadas com o Estágio Curricular Supervisionado, Trabalho de Curso e Atividades Complementares.

Consequentemente, a tentativa reformadora da Resolução nº 9 do CNE/2004, com inserção de uma maior interdisciplinaridade e humanismo nos cursos de Direito, não esconde o descompasso entre a previsão normativa e o universo fático do ensino jurídico. A maioria dos cursos de Direito do Brasil prepara apenas técnicos jurídicos que têm por objetivo aplicar a lei, privilegiando "o caráter de especialização, limitando a compreensão ampla e humanista de formação dos operadores jurídicos [...]” (MAIA; DIÓGENES, 2012, p. 75-76).

O ensino do Direito ainda se atrela ao método tradicional de ensino, que prioriza a memorização e o conteúdo. A aula-conferência ${ }^{9}$ e o uso de compêndios jurídicos ${ }^{10}$, desde a criação dos cursos jurídicos, foram, e continuam sendo, os principais instrumentos metodológicos do ensino jurídico em todos os períodos históricos do Brasil, fazendo crer que esses seriam os instrumentos mais eficientes (BISSOLI FILHO, 2014, p. 38).

Segundo os ensinamentos de Plauto Azevedo (1989, p. 13):

\footnotetext{
${ }^{9}$ A aula-conferência é a forma pedagógica que dá ênfase à atividade do docente, “o professor expõe e os alunos escutam, tomam nota e, eventualmente perguntam ou indagam” (RODRIGUES, 1993, p. 67-68).

10 "O Direito deveria ser ensinado por compêndios breves, claros e bem ordenados, nos quais apenas se contivesse a substância das doutrinas e regras e exceções principais de maior uso, fazendo avultar os princípios na sua conexão e dando predomínio à didática sobre a polêmica" (VENÂNCIO FILHO, 1982, p. 6).

Rev. do Cejur: Prestação Jurisdicional, Florianópolis v.7 n.1, p.125-143, Janeiro-Dezembro. 2019.
} 
[...] essa situação denota mais que uma lacuna importante no aprendizado jurídico. Ela é indicativa de que o ensino jurídico funciona como um sistema fechado em que gravitam os conceitos jurídicos, cultivados com elevado grau de abstração que os afasta dos dados sociais reais, a tal ponto que os juristas tornam-se prisioneiros do tecnicismo que engendra.

Na perspectiva de Paulo Freire, trata-se da "educação bancária", em que o docente é o sujeito que conduz os alunos à memorização mecânica do conteúdo programático, mesmo que com a ajuda de compêndios. Os alunos são recipientes vazios, pois recebem gradativamente os depósitos do docente, que, por seu turno, devem ser memorizados, arquivados e repetidos. Na visão bancária da educação, "o saber é uma doação dos que se julgam sábios aos que julgam nada saber", porém acaba por anular ou minimizar o poder criador e crítico dos discentes, futuros profissionais da área (FREIRE, 1987, p. 59).

A postura didática da grande maioria dos docentes reflete essa perspectiva de Paulo Freire. Poucos são aqueles que questionam o programa de aula e seus propósitos ou os métodos de ensino predominantes nas faculdades; muitos são os que não analisam tampouco decidem o que irão ensinar, por que desejam ensinar ou, ainda, qual o melhor método de ensino para aquela determinada disciplina (GHIRARDI, 2012).

Corroborando essa postura, as grades curriculares dos cursos, com raríssimas exceções, apresentam as disciplinas de teorias gerais (Eixo de Formação Fundamental) nos primeiros semestres, restando, do meio para o final do curso, as disciplinas práticoprofissionais, priorizando-se as matérias ditas dogmáticas. As disciplinas como Direito Civil, Processo Civil, Direito Penal, Processo Penal, Direito do Trabalho e Processo do Trabalho destacam-se nos currículos de formação em detrimento das demais matérias, como, por exemplo, Hermenêutica Jurídica, Teoria do Direito, Sociologia, Antropologia e Filosofia. Além disso, as disciplinas e os docentes dão enfoque ao mecanismo judicial, adjudicatório e adversarial de solução de conflitos.

Os cursos jurídicos dedicam pouca relevância ao estudo dos conflitos. Pouco se fala da justiça do consenso ${ }^{11}$, das técnicas de negociação e de retórica ou de outros métodos de solução de controvérsias diferentes da judicialização dos conflitos, tais como: conciliação,

\footnotetext{
11 “A justiça do consenso busca, para além do tratamento na lide processual, religar o vínculo que se rompeu na lide sociológica, facilitando o diálogo entre as partes, para que, por meio de uma comunicação, possam cooperar entre si, chegando, se possível, ao acordo" (GONÇALVEZ; SEGALA, 2016, p. 233).
}

Rev. do Cejur: Prestação Jurisdicional, Florianópolis v.7 n.1, p.125-143, Janeiro-Dezembro. 2019. 
mediação e arbitragem. Inclusive, parcas são as faculdades brasileiras que disponibilizam alguma disciplina na grade curricular que vise estudar tais métodos ${ }^{12}$.

A formação prática dos alunos, por sua vez, é estruturada de modo a nutrir a cultura da sentença. As faculdades, de forma geral, possuem os escritórios-modelos voltados à prática forense tradicional, que se vincula a "atividades de ensino e ao currículo mínimo das faculdades de direito e caracteriza-se por uma prática jurídica de microlitigação, em regra, individualista, rotinizada e despolitizada" (SOUZA, 2007, p. 40). Entre as principais práticas fomentadas estão a redação de peças processuais, o acompanhamento de processos judicias e a assistência em audiências e sessões. Parcos são os núcleos que estimulam as técnicas de negociação ou utilizam-se de sessões de conciliação ou de mediação para a composição dos $\operatorname{conflitos}^{13}$. Entre as atividades complementares mais exigidas ainda estão os relatórios de audiência de instrução e julgamento, deixando de lado relatórios de sessões de conciliação ou de mediação endoprocessual ou extrajudicial.

A realidade da formação dos bacharéis em Direito, assim, é acentuadamente tecnicista e dogmática. O sistema é edificado sob a ótica de acumulação de conhecimento, com ênfase nas disciplinas do eixo de formação profissional e fomento à cultura da sentença. Entretanto, "a dogmática jurídica é apenas um dos saberes jurídicos” (SANTOS, 2007, p. 63), a reflexão, o diálogo, a participação crítica, a sensibilidade humanística e a vivência são fundamentais para o exercício das funções a serem desempenhadas pelos futuros operadores do Direito, principalmente, pois, como analisado na seção antecedente, a sociedade brasileira continua permeada pela necessidade de judicializar os conflitos e os órgãos do Poder Judiciário não comportam tamanha procura ${ }^{14}$.

\footnotetext{
12 Como matéria obrigatória encontra-se, por exemplo, na Fundação Getúlio Vargas - FGV, na Universidade Federal de Pernambuco - UFPE e na Faculdade de Ciências Sociais de Florianópolis - FCSF/CESUSC; como facultativa, é oferecida na Universidade Federal de Santa Catarina - UFSC e na Pontifícia Universidade Católica de São Paulo -PUC/SP.

${ }^{13}$ Boaventura de Santos Souza (2007, p. 39-41) destaca que, no Brasil, “[...] o estudo dos serviços jurídicos tem sido feito com base em suas categorias opostas: serviços jurídicos inovadores e serviços jurídicos tradicionais. No que toca à atuação das faculdades de direito, estes dois polos opostos materializam-se em dois modelos de intervenção: os escritórios-modelo e as assessorias jurídicas universitárias populares.”. O primeiro modelo, dominante, foi retratado acima. As assessorias jurídicas universitárias, por sua vez, "[...] remetem para uma prática jurídica desenvolvida por estudante de direito que tem hoje uma capacidade nova de passar da clínica jurídica individual, a la americana, para uma forma de assistência e de assessoria jurídica atenta aos conflitos estruturais e de intervenção mais solidária e mais politizada.". O autor, a título de exemplo desse segundo modelo, cita: Direito Achado na Rua (UNB-Brasília); o programa modelar da UFMG, da PUC-RS (Núcleo de Assessoria Jurídica Popular - NAJUP), da UFC (Centro de Assessoria Jurídica Universitária - CAJU) e da UFBA (Serviço de Assessoria Jurídica Universitária).

${ }^{14}$ Os dados do relatório do CNJ apontam que nos últimos anos houve um aumento na força laborativa do Poder Judiciário. Em 2009, os órgãos contavam com 15.946 magistrados em seu quadro e chegou ao número de 18.168 em 2017. O número de servidores e de terceirizados, respectivamente, chegou a 272.093 e a 71.969. Em relação aos demais auxiliares, o relatório aponta que em 2017 os órgãos do Poder Judiciário contaram com o total de Rev. do Cejur: Prestação Jurisdicional, Florianópolis v.7 n.1, p.125-143, Janeiro-Dezembro. 2019.
} 
A próxima seção, portanto, trará outros métodos de ensino do Direito, destacando os métodos de ensino participativo e a conscientização a respeito de outras formas de resolução dos conflitos, pois o operador do direito deve promover o acesso à justiça ${ }^{15}$.

\section{PARA UMA CULTURA DO CONSENSO: A NECESSÁRIA REFORMA NOS CURSOS DE DIREITO NO BRASIL}

A possibilidade de transcender a cultura da sentença, intrínseca na sociedade brasileira, está diretamente vinculada ao habitus dos juristas e ao modo que estes possuem de ver o Direito, os conflitos e a realidade que os cerca. É necessário, para uma desvinculação das crenças que nutrem a cultura da sentença, além das recentes e importantes alterações legislativas, com a implementação de políticas públicas inovadoras, o reconhecimento no meio acadêmico da existência de outras formas de tratamento de conflitos, como também a preparação dos atores jurídicos a partir de uma visão crítica e reflexiva do Direito, não modulada por compêndios jurídicos e restritas aulas expositivas.

A reestruturação do ensino do Direito e das grades curriculares dos cursos de graduação ministrados por todo o Brasil são medidas necessárias. A adoção de uma educação voltada à justiça do consenso, com olhares direcionados à origem do conflito, aos sujeitos envolvidos e às formas adequadas a seu tratamento abrange, como corolário, disciplinas que trabalhem com outros meios de solução de conflitos, que não a solução judicial.

A adaptação para o ensino dos mecanismos consensuais, em geral excluídos da estrutura curricular básica, deve-se dar, inicialmente, na ementa da disciplina de teoria do processo $^{16}$. Tradicionalmente, a disciplina centra-se nas questões a respeito da disputa de interesses, da jurisdição, do processo, do procedimento, da ação e da participação das partes perante o Poder Judiciário ${ }^{17}$. Entretanto, o estudo geral proposto deveria partir dos conflitos, pois estes são inerentes ao ser humano e à vida em sociedade. É natural que as relações intersubjetivas ou intergrupais sejam envolvidas por contraposição de interesses, necessidades

19.026 conciliadores, mediadores, juízes leigos e voluntários, numerário muito superior ao ano de 2016 que chegava a 10 mil, aproximadamente (CNJ, 2018).

15 Aqui o termo é empregado no sentido da terceira onda reformadora proposta por Mauro Cappelletti e Bryant Garth (1988), pois “[...] o direito de acesso à justiça, erigido à dignidade de garantia constitucional, quer dizer bem mais do que a possibilidade de se obterem provimentos 'formais', isto é, decisões judiciais dotadas apenas potencialmente da aptidão de operar transformações no mundo real.” (WAMBIER; WAMBIER 2003, p. 63).

${ }^{16}$ Nesse sentido, defende: Salles (2011, p. 88-107).

${ }^{17}$ Nas palavras de Cândido Dinamarco (2010, p. 276-290), “A disciplina legal do processo, com o desenho dos procedimentos em abstrato e definição das situações ativas e passivas integrantes da relação jurídica processual, constitui, antes e acima de tudo, a disciplina do exercício do poder e um sistema de limitações a ele [...]".

Rev. do Cejur: Prestação Jurisdicional, Florianópolis v.7 n.1, p.125-143, Janeiro-Dezembro. 2019. 
ou valores. E mais, diversos fatores influenciam a maneira de administrar um conflito, dadas as características dos envolvidos, o ambiente, os sentimentos ou, ainda, as experiências pretéritas (FIORELLI; FIORELLI; MALHADAS JUNIOR, 2008) ${ }^{18}$. Ademais, o escopo central do Direito Processual é a pacificação social, com a harmonia das partes e a resolução da lide.

Nessa perspectiva inovadora, assim, o foco central é ensinar aos discentes a percepção do conflito, sua origem, os sentimentos, a maneira que o conflito é encarado pelos envolvidos e como estes lidam com a situação, para, então, examinar as formas possíveis para o seu gerenciamento. Isto porque existem cinco maneiras de os sujeitos envolvidos lidarem com os conflitos instaurados:

[...] no comportamento de fuga - ambas as partes desviam-se da questão, optando por não resolvê-la; na competição - cada parte busca a satisfação das suas necessidades, em detrimento do outro; na acomodação - uma parte busca atender os interesses da outra. Negligenciando as suas próprias necessidades; no compromisso - implica concessões de ambas as partes, em busca de uma solução parcial que as beneficie; na colaboração - envolve o enfrentamento do conflito, na tentativa de se alcançar uma solução que satisfaça, realmente, as partes (RODRIGUES JUNIOR, 2006, p. 42).

A partir desse estudo introdutório, assim, a disciplina de métodos consensuais de resolução de conflitos deveria ser obrigatória nas grades curriculares de todos os cursos de Direto no Brasil. Uma disciplina composta de quatro créditos, partindo do estudo das técnicas de negociação e do papel do negociador até chegar nos institutos da conciliação e da mediação, com o objetivo de transmitir aos discentes a existência de uma ordem consensual de resolução de conflitos, que, segundo os ensinamentos de Petronio Calmon (2007, p. 30):

[...] é negociada e autocompositiva, não adversarial, em que as partes mantêm o controle sobre o procedimento e sobre a decisão final, escolhendo o mecanismo mais apropriado, levando em consideração o tempo necessário para se chegar à solução, o custo, o lugar e a pessoa que eventualmente atuará como facilitador. As partes chegam a soluções suscetíveis de satisfazer os interesses de ambos, conservam o relacionamento entre si e preservam a confidencialidade dos fatos que geraram o conflito, do relacionamento e do próprio procedimento e sua solução.

\footnotetext{
18 Segundo os autores, o conflito tem sua causa-raiz na mudança, seja real, percebida ou ainda apenas uma perspectiva, pois afeta o relacionamento entre pessoas e conduz ao conflito. Também, há causas acessórias que influenciam nos conflitos, tais como: pensamentos rígidos e automáticos, condicionamentos, crenças inadequadas ao contexto, experiências anteriores, influências de natureza sociocultural ou psíquicas, deficiência de comunicação, resistência à mudança, aderência à realidade, diferenças de personalidades e modificações na estrutura de poder (FIORELLI; FIORELLI; MALHADAS JUNIOR, p. 10 e p. 25-41).
}

Rev. do Cejur: Prestação Jurisdicional, Florianópolis v.7 n.1, p.125-143, Janeiro-Dezembro. 2019. 
A disciplina facilitaria uma desconstrução da cultura da sentença, dado que, além de fomentar o papel do conciliador ou do mediador, resgataria a missão dos operadores do Direito de auxiliar os sujeitos a resolverem seus conflitos da melhor forma possível, abrindo os olhares, como corolário, para a ampla gama de mecanismos existentes na sociedade para solução de litígio, que vão muito além da jurisdição.

Complementando, seria necessária a adaptação das grades curriculares para a introdução de uma disciplina que abarque o instituto da arbitragem, pois, como expoente máximo da Justiça Privada e em constante crescimento no Brasil, é uma alternativa ao monopólio do Poder Judiciário. Em que pese tal arbitragem incorporar os elementos procedimentais da jurisdição, é um terceiro imparcial escolhido pelas partes que irá apresentar a decisão ao litígio, e não um agente estatal previamente definido (MARTINS; RUIZ, 2016). Servindo de importante lente de análise e de reflexão para os discentes, o estudo dessas novas matérias obrigatórias, ao lado das disciplinas de Direito Processual, promoveria uma verdadeira mudança de habitus aos futuros juristas.

O eixo de formação prática também seria objeto de mudança. Os núcleos jurídicos abordariam muito mais do que a prática forense tradicional. Os discentes passariam, ao atender a comunidade, a analisar o conflito e as posições dos sujeitos envolvidos para, posteriormente, apresentar a melhor forma de resolução, seja a mediação, a conciliação ou a própria judicialização. Os núcleos jurídicos, por consequência, deveriam dispor de docentes capacitados em técnicas de conciliação e mediação, para, após a prévia análise dos discentes, promoverem as respectivas sessões para a composição dos conflitos.

Segundo Leonard Riskin e James Westbrook (1989), essa expansão do ensino do Direito é necessária, porquanto é capaz de remediar algumas fraquezas do ensino tradicional, como a centralidade do estudo nos compêndios jurídicos e nas leis; o foco no mecanismo judicial; as tendências de reforçar a figura do advogado como defensor adversarial; e as falhas no ensino de habilidades essenciais (entrevistas, aconselhamento, negociação, etc.).

Entretanto, o principal desafio é fomentar e preparar os futuros operadores do Direito para que sejam críticos e reflexivos, não moldados nos saberes codificados "manualescos" - e nas aulas expositivas. É essencial, assim, o desenvolvimento da interdisciplinaridade mencionada nos projetos político-pedagógicos dos cursos, a utilização de outros métodos de ensino, juntamente com a metodologia tradicional, para a construção de um ensino participativo, como uma maior aproximação entre docentes e alunos e com a realidade da sociedade brasileira, em constante transformação. Isto porque compete às universidades 
“organizar esse compromisso, congregando os cidadãos e os universitários em autênticas comunidades interpretativas que superem as usuais interações, em que os cidadãos são sempre forçados a renunciar à interpretação da realidade social que lhes diz respeito" (SANTOS, 1997, p. 224).

Paulo Freire (1997, p. 53), inclusive, há muito alertava para os prejuízos da educação mecanicista:

Enquanto para as posições dogmáticas, mecanicistas, a consciência, que venho chamando crítica, toma forma como uma espécie de epifenômeno, como resultado automático e mecânico de mudanças estruturais, para a dialética, a importância da consciência está em que, não sendo a fazedora da realidade, não é, por outro lado, como já disse, puro reflexo seu. É exatamente neste ponto que se coloca a importância fundamental da educação enquanto ato de conhecimento, não só de conteúdos, mas da razão de ser dos fatos econômicos, sociais, políticos, ideológicos, históricos, que explicam o maior ou menor grau de "interdição do corpo" consciente, a que estejamos submetidos.

Conforme Rubens Sampaio (2000), as disciplinas propedêuticas deveriam ser consideradas as disciplinas por excelência, dado que são responsáveis pela formação do pensamento, do raciocínio jurídico, da argumentação, da compreensão e da reflexão crítica que os discentes deveriam alcançar ao longo do curso. Desta forma, a grade curricular dos cursos de Direito deveria mesclar as disciplinas de teorias gerias (Eixo de Formação Fundamental) com as disciplinas profissionais (Eixo de Formação Profissional) ao longo dos semestres, sem a hierarquização de algumas matérias.

Alterações metodológicas são, igualmente, primordiais para o desenvolvimento da formação do raciocínio crítico jurídico e devem ser seguidas por todos os docentes. São vários os aspectos metodológicos e de técnicas didático-pedagógicas que devem ser considerados, no ensino do Direito, como complemento para construção de uma justiça do consenso, enfatizando-se, aqui, os métodos de ensino participativo ${ }^{19}$.

Segundo Ghirardi (2012), em estudo desenvolvido em parceria com a Fundação Getúlio Vargas, o diálogo socrático é um dos métodos mais lembrados quando se fala em ensino participativo e pode ser muito bem aplicado no ensino do Direito. Esse método baseiase na estratégia pedagógica adotada por Sócrates, que tradicionalmente respondia às indagações de seus discípulos não com explicações definitivas, mas com novas perguntas. O

\footnotetext{
${ }^{19}$ No método de ensino participativo, o discente torna-se agente na construção de seu próprio conhecimento. O estímulo gerado pela participação ativa no processo de aprendizado desenvolve outras habilidades como o raciocínio, o senso crítico apurado, a forte noção para a aplicação adequada do conhecimento, bem como uma grande capacidade de solução dos problemas (GHIRARDI, 2012).
}

Rev. do Cejur: Prestação Jurisdicional, Florianópolis v.7 n.1, p.125-143, Janeiro-Dezembro. 2019. 
diálogo socrático, portanto, centra-se nas formas de pensar do aluno e em como este estrutura suas ideias e desenvolve seus argumentos, técnica que proporcionaria um aprofundamento de reflexão sobre os conceitos jurídicos propostos nas emantas das disciplinas.

Outro método a ser utilizados pelos docentes é o método de caso. Aplicado pioneiramente por Christopher Langdell em suas aulas no curso de Direito de Harvard ao final do século XIX, visa aperfeiçoar o raciocínio jurídico ao solicitar que os discentes analisem criticamente decisões dos tribunais; ou seja, "o método do caso rejeita justamente essa tradição retórica e propõe uma reversão absoluta das premissas básicas que informam o antigo modo de exposição, na medida em que se baseia na postura ativa por parte do aluno" (GHIRARDI, 2012, p. 58). O método de caso objetiva que o discente apreenda tanto o repertório teórico, como também a forma de pensar que caracteriza o Direito.

Um terceiro método aplicável ao ensino do Direito é o role-play. "Como o próprio nome diz, esse método propõe que cada aluno adote um papel, ou ponto de vista, e que atue juridicamente a partir dele" (GHIRARDI, 2012, p. 59). O método incorpora ao espaço da sala de aula a prática dos operadores do Direito, ao permitir que os alunos desenhem estratégias, e possui como objetivo:

[...] aprimorar nos alunos a capacidade de formular e desenvolver as soluções e os instrumentos mais adequados para avançar um conjunto específico de interesses. A premissa é de que o conhecimento jurídico tem por finalidade a ação sobre o real e de que este real é constituído por interesses diversos, algumas vezes convergentes, outras vezes, não raro, conflitantes (GHIRARDI, 2012, p. 59).

Um último método a ser destacado é a simulação, que, embora muito parecida com o role-play, "[...] incorpora como elemento central para sua realização o requisito de que os alunos se vejam submetidos a um elemento de imprevisibilidade” (GHIRARDI, 2012, p. 59). Em linhas gerais, visa desenvolver habilidades necessárias a uma interação bem-sucedida entre os diversos atores jurídicos e as partes envolvidas no conflito, bem como a capacidade de adequá-la às exigências que emergem de seu confronto (GHIRARDI, 2012).

Todos esses métodos de ensino participativo são instrumentos de desenvolvimento de profissionais críticos e reflexivos do direito, que juntamente com o estudo de métodos alternativos à judicialização são capazes de introduzir nos discentes e, por decorrência, no habitus dos futuros juristas um novo modo de ver o Direito, os conflitos e, principalmente, a sociedade brasileira. O Poder Judiciário brasileiro não mais comporta a gama de ações que são propostas todos os dias; não há estrutura suficiente para todos esses 
litígios, e os métodos consensuais são uma possibilidade de transformação e de promoção de acesso à justiça. A mudança cultural para uma justiça do consenso necessita dessa alteração na mentalidade dos operadores do Direito, que devem ser, sobretudo, críticos e reflexivos.

\section{CONCLUSÃO}

Este trabalho teve como propósito inicial analisar, em linhas gerais, o paradigma da cultura da sentença brasileiro e as recentes alterações legislativas que visam a passagem do modelo tradicional de resolução de conflitos para a inserção de uma cultura consensual, por meio das técnicas de conciliação e mediação, já que o Poder Judiciário, atualmente, diante do numerário, não é capaz de resolver todos os litígios instaurados.

Todavia, a cultura da sentença é fruto, para além de uma perspectiva cultural, da mentalidade dos profissionais na área do Direito. Os juristas brasileiros não estão preparados para enfrentar os desafios da contemporaneidade, ao tratar dos meios consensuais de conflitos, e desempenhar um papel transformador. Ao contrário, estão fadados à formação dogmática, ao ensino tecnicista, individual e adversarial, bem como ao distanciamento acadêmico dos reais problemas sociais. Desta forma, a segunda seção retratou a realidade das instituições de ensino jurídico que persistem na cultura da sentença, não possibilitando que os futuros bacharéis vejam soluções diferentes da administração tradicional dos conflitos.

Verificou-se, em seguida, que é possível uma mudança de mentalidade dos juristas brasileiros capaz de transcender o paradigma da cultura da sentença, mas a transformação depende de uma reestruturação geral dos cursos jurídicos. Trata-se de um desafio e um novo olhar sobre o ensino jurídico. A criação de disciplinas isoladas que propiciem o surgimento de uma cultura consensual, como orienta o artigo $6^{\circ}$ da Resolução ${ }^{\circ}$ 125 do CNJ, não é capaz, sozinha, de transcender a cultura da sentença, pois esta encontra-se presente no habitus dos juristas e no modo que estes possuem de ver o Direito, os conflitos e a realidade social. É necessária a formação, já na graduação, de profissionais críticos e reflexivos, preocupados com a justiça social, com a satisfação dos conflitantes e "[...] com a busca de procedimentos que sejam conducentes à proteção dos direitos das pessoas comuns" (CAPPELLETTI; GARTH, 1988, p. 93).

Desta forma, o maior desafio para se alcançar a cultura do consenso é a construção da percepção do conflito e dos interesses dos conflitantes, juntamente com o fomento à preparação de juristas críticos e reflexivos, não moldados unicamente no método 
tradicional de ensino. É essencial a incorporação, nas grades curriculares, de disciplinas obrigatórias que se dediquem ao estudo dos meios consensuais e da arbitragem e ao desenvolvimento da interdisciplinaridade mencionada na Resolução no 9/2004 do Conselho Federal de Educação, mesclando disciplinas dogmáticas e propedêuticas ao longo de todos os semestres. Além disso, deve-se ter um ensino participativo, como uma maior aproximação entre docentes e alunos, bem como entre alunos e a realidade da sociedade brasileira.

\section{REFERÊNCIAS}

AZEVEDO, Plauto Faraco de. Crítica à dogmática e hermenêutica jurídica. Porto Alegre: Sergio Antonio Fabris, 1989.

BISSOLI FILHO, Francisco. Das reformas dos Cursos de Direito às reformas do Ensino Jurídico no Brasil: A importância dos professores e alunos na discussão das reformas e no processo ensino-aprendizagem. In: Educação Jurídica. Horácio Wanderlei Rodrigues, Edmundo Lima de Arruda Júnior (orgs.). 3. ed. corr. Florianópolis : FUNJAB, 2014, p. 9-50.

BRASIL. Ministério da Educação. Resolução CNE/CES 09/2004. Dispõe sobre as diretrizes curriculares para a graduação. http://portal.mec.gov.br/cne/arquivos/pdf/rces09_04.pdf. Acesso em: 8 jun. 2017.

CALMON, Petronio. Fundamentos da mediação e da conciliação. Rio de Janeiro: Forense, 2007.

CAPPELlETTI, Mauro; GARTH, Bryant. Acesso à Justiça. Tradução de Ellen Gracie Nortfleet. Porto Alegre: Sérgio Antônio Fabris Editor, 1988.

CONSELHO NACIONAL DE JUSTIÇA. Justiça em número. 2018. Disponível em: http://www.cnj.jus.br/files/conteudo/arquivo/2018/08/44b7368ec6f888b383f6c3 de40c32167.pdf . Acesso em 19 maio 2019.

DINAMARCO, Candido Rangel. Os Institutos Fundamentais do Direito Processual. In: 2010, p 245-298

Fundamentos do Processo Civil Moderno. Tomo. I. 6 ed. São Paulo: Malheiros,

FÁVERO, Maria de Lourdes de Albuquerque. A Universidade no Brasil: das origens à Reforma Universitária de 1968. Educar, Curitiba: UPFR, n. 28, p.17-36, 2006.

FIORELLI, José Osmir; FIORELLI, Maria Rosa; MALHADAS JUNIOR, Marcos Julio Olivé. Mediação e solução de conflitos: teoria de prática. São Paulo, Atlas, 2008.

FONSECA, Ricardo Marcelo. A cultura jurídica brasileira e a questão da codificação civil no século XIX. In: Quaderni Fiorentini per la Storia del Pensiero Giuridico Moderno, n. ${ }^{\circ}$ 
33/34, Itália, 2004/2005, p.963/983. Disponível em: http://revistas.ufpr.br/direito/article/view/9415. Acesso em: 12 maio 2019.

FREIRE, Paulo. Pedagogia da esperança: um reencontro com a pedagogia do oprimido. Rio de Janeiro: Paz e Terra, 1997.

FREIRE, Paulo. Pedagogia do Oprimido. Rio de Janeiro: Paz e Terra, 1987.

GHIRARDI, José Garcez. O instante do encontro: questões fundamentais para o ensino jurídico. São Paulo: FGV Direito, 2012. Disponível em: http://bibliotecadigital.fgv.br/dspace/bitstream/handle/10438/10303/O\%20instante\%20do\%20 encontro. pdf?sequence=1. Acesso em: 12 maio 2019 .

GONÇALVES, Jéssica; SEGALA, Viviane Maria. Mudanças legislativas no paradigma jurídico tradicional da "cultura da sentença": a inserção do modelo da "justiça consensual" por meio da técnica da mediação de conflitos. In: Revista do CEJUR/TJSC: Prestação Jurisdicional, v. IV, n. 01, p. 225-239, dez. 2016. Disponível em: https://revistadocejur.tjsc.jus.br/cejur/article/view/145. Acesso em: 12 maio 2019.

LANÇANOVA, Jonatas Luis. O poder judiciário em crise e a mediação como meio alternativo de solução dos conflitos. In: Revista Direito em Debate. Ano XXIII, $\mathrm{n}^{\circ} .: 42$, Juldez, 2014.

MAIA, Christianny Diógenes Maia; DIÓGENES, Thanara Rocha. Crítica ao ensino jurídico brasileiro. Ensino jurídico: os desafios da compreensão do direito. Estudos em homenagem aos 10 anos do curso de direito da Faculdade Christus. Fortaleza: Faculdade Christus, 2012.

MARTINS, Heitor Filipe Men; RUIZ, Ivan Aparecido. Arbitragem: incidência e os reflexos práticos na sociedade contemporânea. Universitas Jus, Brasília, v. 27, n. 3, p. 190-202, 2016.

OLIVEIRA, Juliana Ferrari de. Ensino jurídico: experiências inovadoras. Rio de Janeiro: Lumen Juris, 2010.

RISKIN, Leonard; WESTBROOK, James. Integrating dispute resolution into Satandard firstyear courses: the missouri plan. Journal of Legal Education, vol. 39, 4, 1989, p. 509-522.

RODRIGUES, Horácio Wanderlei. Ensino jurídico e direito alternativo. São Paulo: Acadêmica, 1993.

RODRIGUES JUNIOR, Walsir Edson. A prática da mediação e o acesso à justiça. Belo Horizonte: Del Rey, 2006.

SALLES, Carlos Alberto de. Arbitragem em contratos administrativos. Rio de Janeiro: Forense, 2011.

SALLES, Carlos Alberto de. Mecanismos alternativos de solução das controvérsias e acesso à justiça: inafastabilidade da tutela jurisdicional. In: FRUZ, Luiz (coord.). AZEVEDO, André Gomma de (org.). Manual de Mediação Judicial. 5. ed. 2015. São Paulo: 2006. 
SAMPAIO, Rubens G. Crise ética e a advocacia. Porto Alegre: Sergio Antônio Fabris Editor, 2000.

SANTOS, Boaventura de Sousa. Para uma revolução democrática da justiça. São Paulo: Cortez, 2007.

SANTOS, Boaventura de Sousa. Pela mão de Alice: o social e o político na pósmodernidade. São Paulo: Cortez, 1997.

SCKELL, Soraya Nour. Os juristas e o direito em Bourdieu: a conflituosa construção histórica da racionalidade jurídica. Tempo soc., São Paulo, v. 28, n. 1, p. 157178, Abr. 2016. Disponível em: http://www.scielo.br/scielo.php?

script=sci_arttext\&pid=S0103-20702016000100157\&lng=en\&nrm=iso. Acesso em: 14 maio 2019.

VENÂNCIO FILHO, Alberto. Das arcadas ao bacharelismo. 2. ed. São Paulo: Perspectiva, 1982.

WAMBIER, Luiz Rodrigues; WAMBIER, Teresa Arruda Alvim. Anotações sobre a efetividade do processo. Revista dos Tribunais, ano 92, n. 814, agosto, 2003.

WATANABE, Kazuo. Política pública do poder judiciário nacional para tratamento adequado dos conflitos de interesses. 2017. Disponível em: http://www.tjsp.jus.br/Download/Conciliacao/Nucleo/ParecerDesKazuoWatanabe.pdf. Acesso em: 15 maio 2019. 